\title{
THE EFFECT OF PROFESSIONALISM ON EMPLOYEE WORK PRODUCTIVITY AT SAKURA JAYA COMPANY
}

\author{
Rinintha Parameswari \\ (rininthapwari@gmail.com) ${ }^{1}$ ) \\ Fidelis Wato Tholok \\ (fidelljst@gmail.com)2) \\ Pujiarti \\ (pujikuswandip@gmail.com)3) \\ 1) 2) 3)Universitas Buddhi Dharma
}

\begin{abstract}
The more professional human resources are in control, the vision and mission and goals of the company will be achieved effectively, efficiently, and productively (Budiharjo, 2015: 5). Therefore, human resource management is needed that is not only able to recruit it, but able to retain competent employees and improve the performance of its employees so the company can continue to develop better and be able to compete with its competitors (Budiharjo, 2015: 8).

The results showed that: 1) There was an influence of professionalism on employee work productivity, as evidenced by the tcount for the Professionalism $(X)$ variable of 20,830, while the $t$-table value for $N=85$ was 1,988 . So 20,830>1,988, then $\mathrm{HO}$ is rejected and Ha is accepted, it can be stated that Professionalism (X) has a significant effect on Employee Productivity $(Y)$. Probability value (significance) = 0,000 . So the probability is 0,000 below 0.05 . Thus, $\mathrm{H} 0$ is rejected and Ha is accepted, it can be concluded that there is a positive and significant effect between the professional variable $(\mathrm{X})$ on the Employee Productivity variable $(\mathrm{Y})$, because the probability value is smaller than 0.05. 2) There is an influence of Professionalism on Employee Work Productivity, as evidenced by the $\mathrm{R}$ Square value of 0.839 . This shows that $83.9 \%$ Professionalism (X) affects Employee Productivity (Y), while the remaining $16.1 \%$ is influenced by other factors not examined in this study.
\end{abstract}

Keywords: Professionalism and Productivity of Employees 


\section{PRELIMINARY}

Human resources are the only resources that have the intellect, feelings, desires, abilities, skills, knowledge, encouragement, power and work. A potential resource is very influential on the efforts of the organization in achieving its goals. However advanced technology is, information is developed, capital is available and sufficient, but without human resources, it will be difficult for organizations to achieve their goals.

\section{Human Resource Management Function}

According to Gary Dessler (2010: 4); Classifying the scope of Human Resource Management into two main functions. The two functions of Human Resource Management are:

1. Management Function

a. Planning First determine the goals to be achieved by the company and how to achieve these goals. For a personnel manager planning means setting up a personnel program in advance that will help the company's goals.

b. Organizing Carrying out the division of tasks or the structure of the relationship between work grouping of workers so an organization can be driven as a whole in order to achieve the goals set.

c. Directing After planning and organizing have been established, then this function is as an implementation such as showing and notifying employee mistakes, training to think of an incentive, reward or sanction to employees in accordance with the Discipline they achieve.

d. Controlling Actions or activities undertaken by managers to conduct observations, research, and assessments of the implementation of all organizational activities that are currently or have been running to achieve the objectives in accordance with the plans set.

2. Operational Function

a. Procurement It is an effort to provide the needed labor according to the number and quality or specific expertise by finding the source of origin needed for the workforce, carrying out the selection process and utilizing the workforce on the principle of adjusting between the needs and supply of labor.

b. Development Is a process of increasing abilities and skills, both managerial skills and operational technical capabilities, because the withdrawal, selection and placement of employees carried out properly does not necessarily guarantee that they can carry out their work in a new place as well as possible. For this reason, it is necessary to develop new employees as well as possible. For this reason, it is necessary to develop new employees in order to improve their knowledge, skills and abilities. Usually this is done through employee education and training programs.

c. Compensation This compensation is defined as giving fair or reasonable rewards or awards from the company to its employees for the achievements that have been given by employeesThis compensation can be in the form of wages, salaries, incentives, benefits, and other means that can provide satisfaction to employees.

d. Integration efforts influence employees so that all their actions can be directed to goals that benefit the company, work and coworkers.

e. Maintenance This function is concerned with how to maintain employees so they are comfortable and able to work well in the company. Good employee 
maintenance will provide good things, one of which is a low labor turnover rate These two things need to be considered by the company, namely maintenance of physical conditions and employee attitudes.

f. Separation It is a company activity to return workers to the community after dedicating their energy within the company including: retirement, temporary lay off, respectful dismissal, dismissal, replacement of labor, pperational function

\section{Profesionalisme}

Professional means expert in the field. If a manager claims to be a professional he must be able to show that he is an expert in his field must be able to show high quality in its work. Talking about professionalism reflects one's attitude towards his profession. Professionalism which is defined behavior, ways, and qualities that characterize a profession.

A person is said to be professional if his work has the technical or ethical standard characteristics of a profession (Oerip and Uetomo, 2000: 264-265). The term professional applies to all officers from the upper level to lower level. Professionalism can be interpreted as a person's abilities and skills in doing work according to their respective fields and levels.

The term professionalism comes from the word professional which is interpreted by Wojowasito and Poerwodaminta as having expertise, so the word professionalism refers to the appearance of people who do their jobs. Professionalism is also synonymous with appearance or professionalism, according to Keith Davis in Mangkunegara (2007), formulated as a function of ability and Motivation or P = F (A x $\mathrm{M})$, where $\mathrm{P}$ is a performance or appearance while $\mathrm{A}$ is an ability or ability that includes knowledge and skills (Physical and Engineering), as for motivation which includes the environment and motivation (Suitability of salary, additional income and awards). Thus to be able to improve their appearance and professionalism, an increase in factor A (ability) is needed which automatically increases their knowledge and skills, as well as improving their environment and motivation.

The following average salary based on line of business. Classification based on KBLI seen, the average (mean) labor wage of Rp 2.91 million. This "labor" includes all types of work, including employees 


\section{Tabel 1}

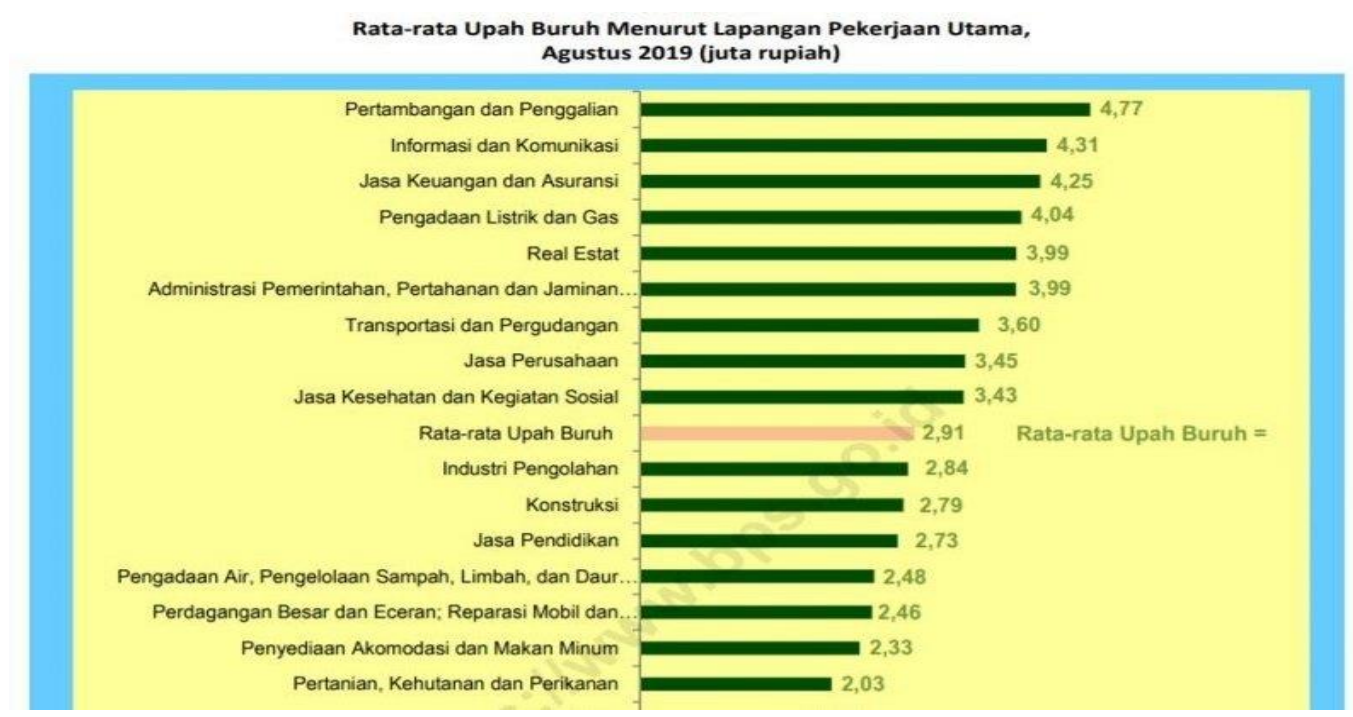

\section{Work Productivity}

Sukamto (1995), in his book entitled replication production management states that: "Productivity is the value of output in relation to a certain set of inputs. The increased productivity which means the amount of resources used with the number of goods and services produced is increasing and improving ". Meanwhile, according to Moekijat (1999), productivity is "Comparison of a certain number of outputs with a certain number of inputs for a certain period of time".

The Indonesian National Productivity Council has formulated a complete definition of productivity as follows (umar, 2002):

1. Productivity is basically a mental attitude that always has view that the quality of life today is better than yesterday and tomorrow is better than today.

2. In general, productivity implies a comparison between the results achieved (output) with the overall resources used (input).

3. Productivity has two dimensions, effectiveness that leads to maximum work achievement, achieving targets related to quality, quantity and time. The second is efficiency related to efforts to compare inputs with the realization of their use or how the work is carried out.

The most famous measure of productivity is related to labor which can be calculated and divided by expenses and the amount used or hours worked for employees. An industrial company is a process unit that processes resources (inputs) into (outputs) with a certain transformation. In this process there is an increase in the value of the resource so that the economic output produced has more value than before processing. Attention and expectations of productivity are bigger and fundamentally. The benefits of productivity are comprehensive and strategic, namely:

a) Productivity can be used as a measure of the company's performance and competitiveness.

b) The effect of productivity on macroeconomic work. An organization can make a big leap in improving productivity. 
c) An organization can utilize employees and supervisors with new attitudes in traditional work processes efficiently to improve higher living standards.

d) The company can increase productivity with existing commitments without replacing production facilities such as machinery / equipment, labor and others.

e) Productivity can control inflation.

f) Management can improve the way it manages complexity by innovating in the planning and implementation process based on experience and achieving productivity.

g) Management can motivate workers towards achieving high productivity.Produktivitas dapat diukur pada berbagai tingkat organisasi (nasional, industry maupun tingkat perusahaan).

\section{RESEARCH METHODOLOGY}

This research is an observational analytic study, where the researcher makes direct observations to the respondents by distributing questionnaires to be analyzed using quantitative research methods. Quantitative research takes the distance between the researcher and the object under study. Quantitative research uses formal instruments, standards and measures (Sukmadinata, 2006: 95). The research framework is as follows:
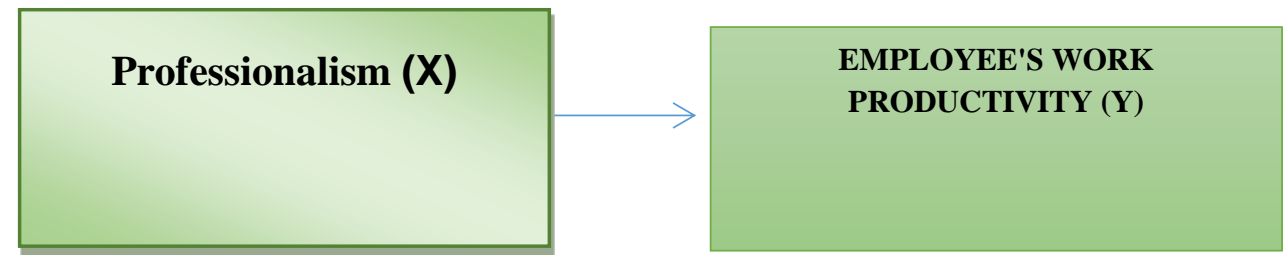

According to Sugiyono (2010: 58) operational variables are anything in the form of what is determined by researchers to be studied so information is obtained about it, then conclusions are drawn. Meanwhile, according to Indriantoro and Supomo (2002: 69). The operational definition of a variable is the determination of construct that it becomes a variable that can be observed and measured by determining what is needed to achieve a certain goal.

Tabel 3.1

(Operasional Variabel)

\begin{tabular}{|c|l|l|c|}
\hline Variabel & \multicolumn{1}{|c|}{ Dimension } & \multicolumn{1}{c|}{ Indicator } & Item \\
\hline $\begin{array}{c}\text { Professionalis } \\
\text { m (X) }\end{array}$ & 1. Ability & $>$ Physical & $1,2,3$ \\
& & $>$ Technique & $4,5,6$ \\
\cline { 2 - 4 } $\begin{array}{c}\text { Sources: } \\
\text { Keith Davis } \\
\text { dalam }\end{array}$ & 2. Motivation / & $>$ conformity salary & 7,8 \\
$\begin{array}{c}\text { Mangkunegara } \\
\text { (2007) }\end{array}$ & & $>$ Additional & 9,10 \\
income & $11,12,13$ \\
& & $>$ Award & \\
\hline
\end{tabular}




\begin{tabular}{|c|c|c|c|}
\hline \multirow{4}{*}{$\begin{array}{c}\text { Employee } \\
\text { Work } \\
\text { Productivity } \\
\text { (Y) } \\
\text { Sources: } \\
\text { Anwar Prabu } \\
\text { Mangkunegara } \\
\text { (2006:9) }\end{array}$} & $\begin{array}{l}\text { 1. Work results in quality } \\
\text { and quantity }\end{array}$ & $\begin{array}{l}\text { Carry out their } \\
\text { duties }\end{array}$ & $1,2,3$ \\
\hline & $\begin{array}{l}\text { 2. Achieved by someone } \\
\text { employee }\end{array}$ & $\begin{array}{l}\text { Karyawan } \\
\text { Employee ability }\end{array}$ & $4,5,6$ \\
\hline & 3. Carry out their duties & $\begin{array}{l}\text { Karyawan } \\
\text { Employee skills }\end{array}$ & $7,8,9$ \\
\hline & $\begin{array}{l}\text { 4. In accordance with the } \\
\text { responsibilities given } \\
\text { to him }\end{array}$ & $>$ Be on time & $10,11,12,13$ \\
\hline
\end{tabular}

In this study the population is the number of all employees in the Sakura Jaya Company 570 employees by calculating the sample size carried out using the Slovin technique according to Sugiyono (2011: 87) as follows:

$\mathrm{n}=$ Number of Samples

$\mathrm{N}=$ Total Population

$\mathrm{e}^{2}=$ Desired Limits of Accuracy

$$
\begin{aligned}
\mathrm{n} & =\frac{\mathrm{N}}{1+\mathrm{Ne}^{2}} \\
& =\frac{570}{1+570(0.1)^{2}} \\
& =\frac{570}{1+570(0.01)} \\
& =\frac{570}{6,7}=85
\end{aligned}
$$

From these calculations, the results obtained 85 people. So the number of samples studied was 85 respondents at the Sakura Jaya Company. The data collection technique used in this study was the Field Research Technique, which was carried out by going directly to the field (survey) using a questionnaire data collection tool for direct interviews with respondents.

Literature research techniques, which are carried out to support theoretical or conceptual ideas about variables or conceptual about research variables, which in this case is supported by data collection tools through text books or literature that can be used as material for study in this study.

Observation, inexample collecting data in the form of direct observation of the object under study. This study uses a questionnaire that contains instruments, namely instruments to measure (1) Professionalism (2) Employee Productivity. The instruments 
are arranged in the form of a questionnaire that provides five options with the alternative options provided consisting of:

a. The Answers strongly agree with value $=5$.

b. The Answers agree with value $=4$.

c. The Answer simply agree with value $=3$

d. The Answer disagrees with value $=2$

e. The Answer strongly disagree with a value $=1$

\section{DISCUSSION RESULT}

a. Motivation Variable Validity Test $(X)$

To find out the results of the analysis of the Professionalism $(X)$ variable, researchers used a computer program SPSS version 20 for Windows Input professionalism variable data $(X)$ which is an ordinal data from a sample of 85 with 13 questions as follows:

Tabel 4.1

Test the Validity of Variable Professionalism (X)

\begin{tabular}{|c|c|c|c|}
\hline \multirow{3}{*}{ Pertanyaan } & \multicolumn{3}{|c|}{ Motivasi (X) } \\
\cline { 2 - 4 } & $\mathbf{r}_{\text {hitung }}$ & $\begin{array}{c}\mathbf{r}_{\text {tabel }} \mathbf{N}=85 \\
\text { Keterangan }\end{array}$ \\
\hline 1 & $0,816^{* *}$ & 0.210 & Valid \\
2 & $0,588^{* *}$ & 0.210 & Valid \\
3 & $0,670^{* *}$ & 0.210 & Valid \\
4 & $0,419^{* *}$ & 0.210 & Valid \\
5 & $0,804^{* *}$ & 0.210 & Valid \\
6 & $0,647^{* *}$ & 0.210 & Valid \\
7 & $0,582^{* *}$ & 0.210 & Valid \\
8 & $0,789^{* *}$ & 0.210 & Valid \\
9 & $0,653^{* *}$ & 0.210 & Valid \\
10 & $0,570^{* *}$ & 0.210 & Valid \\
11 & $0,592^{* *}$ & 0.210 & Valid \\
12 & $0,630^{* *}$ & 0.210 & Valid \\
13 & $0,762^{* *}$ & 0.210 & Valid \\
\hline
\end{tabular}

Source: Processed Data Results (SPSS 20), 2020

Based on the above table, it can be seen that for each statement on the Professionalism $(X)$ variable, all instruments can be said to be valid, because the calculated $r$ value is far greater than the rtable value available for $\mathrm{N}=85$ which is 0.210 .

b. Test the Validity of Employee Productivity Variables (Y)

To find out the results of the analysis of the Employee Productivity (Y) variable, researchers used the SPSS version 20 computer program for Windows. Input the Employee Productivity (Y) variable data which is an ordinal data of a sample of 85 with 13 questions as follows: 
Tabel 4.2

Test the Validity of Employee Productivity Variables (Y)

\begin{tabular}{|c|c|c|c|}
\hline \multirow{2}{*}{ Pertanyaan } & \multicolumn{3}{|c|}{ Kepuasan Kerja Karyawan (Y) } \\
\cline { 2 - 4 } & rhitung & $\begin{array}{c}\mathbf{r}_{\text {tabel }} \\
\mathbf{N}=85\end{array}$ & Keterangan \\
\hline 1 & $0,764^{* *}$ & 0.210 & Valid \\
2 & $0,668^{* *}$ & 0.210 & Valid \\
3 & $0,779^{* *}$ & 0.210 & Valid \\
4 & $0,567^{* *}$ & 0.210 & Valid \\
5 & $0,304^{* *}$ & 0.210 & Valid \\
6 & $0,677^{* *}$ & 0.210 & Valid \\
7 & $0,553^{* *}$ & 0.210 & Valid \\
8 & $0,766^{* *}$ & 0.210 & Valid \\
9 & $0,630^{* *}$ & 0.210 & Valid \\
10 & $0,567^{* *}$ & 0.210 & Valid \\
11 & $0,553^{* *}$ & 0.210 & Valid \\
12 & $0,659^{* *}$ & 0.210 & Valid \\
13 & $0,603^{* *}$ & 0.210 & Valid \\
\hline
\end{tabular}

Sumber: Hasil Olahan Data (SPSS 20), 2020

Based on the table above, it can be seen that for each statement on the Employee Productivity $(\mathrm{Y})$ variable, all instruments can be said to be valid, because the calculated $r$ value is far greater than the rtable value for $\mathrm{N}=85$ which is 0.210 .

\section{Reliability Test}

The Reliability Test was carried out using the Cronbach Alpha Test.

Professionalism Variable Reliability Test (X)

Tabel 4.3

Professional Variable Reliability Test (X)

Reliability Statistics

\begin{tabular}{|r|r|}
\hline Cronbach's Alpha & N of Items \\
\hline, 887 & 13 \\
\hline
\end{tabular}

Source: Processed Data Results (SPSS 20), 2020

Based on the table above, to test the reliability of the Professionalism $(X)$ variable with a rtable value of 0.210 , while the Cronbach's Alpha value is 0.877 , so it can be concluded that the ralpha is positive and greater or $0.877>0.210$, thus the research instrument regarding the Professional variable $(X)$ is Realibel

\section{Reliability.}

Employee Productivity Variable Test Reliability (Y)

Tabel 4.4

Employee Productivity Variable Test Reliability (Y)

Reliability Statistics

\begin{tabular}{|r|r|}
\hline Cronbach's Alpha & N of Items \\
\hline, 871 & 13 \\
\hline
\end{tabular}

Source: Processed Data Results (SPSS 20), 2020 
Based on the table above, for the reliability test variable Employee Productivity (Y) with a rtabel value of 0.210 , while the Cronbach's Alpha value of 0.871 , so it can be concluded that ralpha is positive and greater or $0.871>0.210$, then the research instrument regarding the Satisfaction variable Employee Work (Y) is Reliable.

\section{Uji Normalitas}

Normality test is used to determine whether the population data is normally distributed or not.

Tabel 4.5

Normality Test Results

One-Sample Kolmogorov-Smirnov Test

\begin{tabular}{|ll|r|r|}
\hline & & $\begin{array}{c}\text { Profesion } \\
\text { alisme } \\
(\mathrm{X})\end{array}$ & $\begin{array}{c}\text { Produktivit } \\
\text { as Kerja } \\
\text { Karyawan } \\
(\mathrm{Y})\end{array}$ \\
\hline $\mathrm{N}$ & Mean & 52,5412 & 52,6471 \\
Normal & Std. & 7,50643 & 7,03343 \\
Parametersa,b & Deviation &, 118 &, 106 \\
Most & Absolute &, 064 &, 075 \\
Differences & Positive &,- 118 &,- 106 \\
Kolmogorov-Smirnov Z & 1,091 &, 974 \\
Asymp. Sig. (2-tailed) &, 185 &, 299 \\
\hline
\end{tabular}

a. Test distribution is Normal.

b. Calculated from data.

Source: Processed Data Results (SPSS 20), 2020

Based on the above table, the significance value (2-tailed) Professionalism (X) variable is 0.185, while the Employee Productivity (Y) variable is 0.299. Both significance values (2tailed) of the measuring instrument are above 0.05 , so the data are said to be normally distributed. While the Kolmogorov-Smirnov $Z$ value of Professionalism $(X)$ variable is 1.091, while for Employee Productivity (Y) variable is 0.974, it means that the residual data is normally distributed.

\section{Normality Test Results}

The normality test using the normal probability plot requires that the data distribution must be around the diagonal line region and follow the direction of the diagonal line. Based on the picture above it can be concluded that the data in this study meet the normal probability plot requirements so that the regression model in the study meets the assumption of normality (normally distributed). This means that the data in this study come from populations that are normally distributed. 
Simple Linear Regression Test

Tabel 4.6

Coefficients ${ }^{\mathrm{a}}$

\begin{tabular}{|c|c|c|c|c|c|}
\hline \multirow[t]{2}{*}{ Model } & \multicolumn{2}{|c|}{$\begin{array}{l}\text { Unstandardized } \\
\text { Coefficients }\end{array}$} & \multirow{2}{*}{\begin{tabular}{|c}
$\begin{array}{c}\text { Standardized } \\
\text { Coefficients }\end{array}$ \\
Beta
\end{tabular}} & \multirow[t]{2}{*}{$\mathrm{t}$} & \multirow[t]{2}{*}{ Sig. } \\
\hline & $\mathrm{B}$ & $\begin{array}{l}\text { Std. } \\
\text { Error }\end{array}$ & & & \\
\hline (Constant) & 7,542 & 2,187 & & 3,448 & ,001 \\
\hline Profesionalisme $(X)$ & 858 & ,041 & 916 & 20,830 & ,000 \\
\hline
\end{tabular}

a. Dependent Variable: Produktivitas Kerja Karyawan (Y)

Source: Processed Data Results (SPSS 20), 2020

From the table above we get the simple linear regression equation as follows:

$$
Y=7.542+0.858 X
$$

The constant value a means that when the variable Professionalism $(X)$ is zero or not influenced by Employee Productivity (Y), then Employee Productivity is 7,542. While the regression coefficient $\mathrm{b}$ means that if the variable Professionalism $(X)$ increases by one unit, the Employee Productivity $(\mathrm{Y})$ will remain at 0.858 .

\section{Hypothesis test}

Based on the coefficients table above, the calculated value for the Professionalism (X) variable is 20,830, while the value of the table for $N=85$ is 1,988. So 20,830>1,988, then $\mathrm{H} 0$ is rejected and Ha is accepted, it can be stated that Professionalism (X) has a significant effect on Employee Productivity $(Y)$. Probability value (significance) $=0,000$. So the probability is 0,000 below 0.05 . Thus, $\mathrm{H} 0$ is rejected and Ha is accepted, it can be concluded that there is a positive and significant influence between the Professionalism $(\mathrm{X})$ variable on the Employee Productivity variable $(\mathrm{Y})$, because the probability value is smaller than 0.05 .

\section{Coefficient of Determination}

Tabel 4.7

Model Summary ${ }^{b}$

\begin{tabular}{|c|c|c|c|c|}
\hline $\begin{array}{l}\text { Mod } \\
\text { el }\end{array}$ & $\mathrm{R}$ & $\begin{array}{c}\mathrm{R} \\
\text { Square }\end{array}$ & $\begin{array}{l}\text { Adjusted R } \\
\text { Square }\end{array}$ & $\begin{array}{c}\text { Std. Error of } \\
\text { the } \\
\text { Estimate }\end{array}$ \\
\hline 1 & $916^{\mathrm{a}}$ & 839 & ,837 & 2,83532 \\
\hline
\end{tabular}

a. Predictors: (Constant), Profesionalisme (X)

b. Dependent Variable: Produktivitas Kerja

Karyawan (Y)

Sumber: Hasil Olahan Data (SPSS 20), 2020 
Based on the calculation in the above table, the influence of the two variables is tested, and based on the Summary Model table, the R Square value of 0.839 is generated. This shows that $83.9 \%$ Professionalism $(X)$ affects Employee Productivity $(\mathrm{Y})$, while the remaining $16.1 \%$ is influenced by other factors not examined in this study.

Based on the results of research analysis using statistical methods, so it can be seen the meaning of the influence of the independent variables, namely Professionalism on the dependent variable, namely the Work Productivity of Sakura Jaya Employees. This study involved 85 respondents, namely employees of PT. White Elephant Elastic. Then for the results of hypothesis testing and discussion of the hypothesis test that was tested statistically using the SPSS version 20 data processing program.

Based on the coefficients table 4.6 above Professionalism $(X)$ has a significant effect on Employee Productivity $(\mathrm{Y})$, because the tcount for the Professionalism (X) variable is 20,830 , while the ttable value for $\mathrm{N}=85$ is 1,988 . So $20,830>1,988$, then $\mathrm{H} 0$ is rejected and $\mathrm{Ha}$ is accepted, it can be stated that ProX) has a significant effect on Employee Productivity (Y). Probability value (significance) $=0,000$. So the probability is 0,000 below 0.05 . Thus, $\mathrm{H} 0$ is rejected and $\mathrm{Ha}$ is accepted, it can be concluded that there is a positive and significant influence between the Professionalism $(X)$ variables towards Employee Work Productivity variable $(\mathrm{Y})$, because the probability value is smaller than 0.05., with an $\mathrm{R}$ Square value of 0.839 . This shows that $83.9 \%$ Professionalism $(\mathrm{X})$ affects Employee Productivity $(\mathrm{Y})$, while the remaining $16.1 \%$ is influenced by other factors not examined in this study.

The conclusions that can be drawn based on the results of data analysis regarding the effect of Professionalism on Sakura Jaya Employee Productivity, the conclusions of this study are as follows:

1. There is an influence of Professionalism on Employee Work Productivity, as evidenced by the tcount for the Professionalism (X) variable of 20,830, while the t-table value for $\mathrm{N}=85$ is 1,988 . So $20,830>1,988$, then $\mathrm{H} 0$ is rejected and $\mathrm{Ha}$ is accepted, it can be stated that Professionalism $(\mathrm{X})$ has a significant effect on Employee Productivity (Y). Probability value (significance) $=0,000$. So the probability is 0,000 below 0.05 . Thus, $\mathrm{H} 0$ is rejected and $\mathrm{Ha}$ is accepted, it can be concluded that there is a positive and significant influence between the Professionalism $(X)$ variable on the Employee Productivity variable $(\mathrm{Y})$, because the probability value is smaller than 0.05 .

2. There is an influence of Professionalism on Employee Work Productivity, as evidenced by the $\mathrm{R}$ Square value of 0.839 . This shows that $83.9 \%$ Professionalism (X) affects Employee Productivity (Y), while the remaining $16.1 \%$ is influenced by other factors not examined in this study.

\section{REFERENSI}

A.A. Anwar Prabu Mangkunegara. 2006. Evaluasi Kinerja Sumber Daya. Manusia. Jakarta: Refika Aditama. 
Alex S. Nitisemito, 1991. Manajemen Personalia (Manajemen Sumber Daya Manusia). Jakarta: Ghalia Indonesia.

Arep, Ishak dan Hendri Tanjung. 2003. Manajemen Sumber Daya Manusia. Jakarta: Universitas Trisakti.

Arikunto, S. 2010. Prosedur Penelitian Suatu Pendekatan Praktik. Jakarta: Rineka Cipta.

Arikunto, Suharsimi, 2002. Prosedur Penelitian, Suatu Pendekatan Praktek. Jakarta: PT. Rineka Cipta.

2006. Prosedur Penelitian Suatu Pendekatan Praktik. Jakarta: Rineka Cipta.

Bungin, Burhan. 2005. Metodologi Penelitian Kuantitatif. Kencana Prenada Media. Group: Jakarta.

Cooper, D. R, dan P. S. Schindler. 2006. Business Research Methods. 9* Edition. McGrawHill, New York.

Erlina, Sri Mulyani, 2007. Metodologi Penelitian Bisnis : Untuk Akuntansi dan. Manajemen, Cetakan Pertama USU Press, Medan.

Ghozali, Imam. 2005. Aplikasi Analisis Multivariate dengan SPSS. Semarang: Badan Penerbit UNDIP.

Halawa, Nopelius. 2018. Pengaruh Profesionalisme Terhadap Produktivitas Kerja Pegawai Di Dinas Lingkungan Hidup Kabupaten Nias Selatan. Sekolah Tinggi Ilmu Ekonomi Nias Selatan Telukdalam.

Hanafi, Agustina. 2007. Pengaruh Kualitas Dan Profesionalisme Terhadap Produktivitas Kerja (Kajian Pada Departemen SDM Pada PT. Pertamina Persero (Tbk), PT Semen Baturaja Persero (Tbk), PT PUSRIPersero (Tbk), PT Perusahaan Listrik NegarA (PLN) Persero (Tbk), dan PT. Bukit Asam Persero (Tbk). Jurnal Kajian Ekonomi dan Bisnis. Vol 9, no. 1.

Handayaningrat, S. 1995. Pengantar Ilmu Administrasi dan Manajemen. Jakarta: PT Gramedia Pustaka Utama.

Handoko, Hani. 2001. Manajemen Personalia dan Sumber Daya Manusia. Edisi 2. BPFE Yogyakarta. 2007. Manajemen Personalia dan Sumberdaya Manusia. Yogyakarta: BPFE.

Hasibuan, Malayu S.P., 1996, Manajemen Dasar, Pengertian dan Masalah, Edisi. Kedua, Jakarta: PT Toko Gunung Agung. 2000. Manajemen Sumber Daya Manusia. PT. Gunung Agung. Jakarta. 2012. Manajemen Sumber Daya Manusia. Jakarta: PT. Bumi Aksara.

Hidayat, A.A. 2007. Metode Penelitian dan Teknik Analisis Data.Jakarta: Salemba Medika.

2012. Pengantar Ilmu Kesehatan Anak untuk Pendidikan Kebidanan. Jakarta: Salemba Medika.

Husein, Umar. 2011. Metode Penelitian Untuk Skripsi dan Tesis Bisnis Edisi 11. Jakarta: PT Raja Grafindo Persada.

Ibrohim. 2017. Pengaruh Kompetensi Profesional Dan Motivasi Kerja Terhadap Kinerja Guru Dimoderasi Kepemimpinan Kepala Sekolah. PPS Unisbank Semarang

Laksmiari, Ni Putu Pradita. 2019. Pengaruh Motivasi Kerja Terhadap Produktivitas Kerja Karyawan Pada Perusahaan Teh Bunga Teratai Di Desa Patemon Kecamatan Serrit. Jurnal Pendidikan Ekonomi Undiksha.

Mahmudi. 2005. Manajemen Kinerja Sektor Publik. Yogyakarta: UPP AMP YKPN.

Manullang, M. Dan Manullang Marihot. 2004. Manajemen Sumber Daya Manusia. Edisi Pertama. Cetakan Pertama. Yogyakarta: BPFE. 
Moekijat. (1989), Manajemen Kepegawaian, Bandung: Mandar Maju. 1984. Dasar-Dasar Motivasi, Bandung: Sumur Bandung.

Moeljono, Djokosantoso. 2003. Budaya Korporat Dan Keunggulan. Korporasi. Jakarta: Elex Media Komputindo.

Muchdarsyah Sinungan, 1997. Produktivitas Apa dan Bagaimana, edisi ke II, Bumi Aksara, Jakarta.

Riduwan dan Sunarto. 2007. Pengantar Statistika. Bandung: CV Alfabeta. , 2011. Pengantar Statistika: Untuk Penelitian Pendidikan,. Sosial, Ekonomi, Komunikasi dan Bisnis. Bandung: Alfabeta.

Sedarmayanti, 2008, Manajemen Sumber Daya Manusia, Reformasi Birokrasi dan Manajemen Pegawai Negeri Sipil, Bandung. 2009. Sumber Daya manusia dan produktivitas. CV Mandar Maju. Bandung.

Sekaran, Uma. 2006. Metodologi Penelitian untuk Bisnis, Edisi 4, Buku 1, Jakarta: Salemba Empat.

Siagian, Sondang P. 2009. Kiat Meningkatkan Produktivitas Kerja. Jakarta: PT. Rineka Cipta.

Simamora, Henry. 2006. Manajemen Sumber Daya Manusia. Yogyakarta: STIE YKPN.

Steers, Richard M, 1980. Terj: Magdalena Jamin, Efektivitas Organisasi, Jakarta: Erlangga,

Sugiyono. 2006. Metode Penelitian Kuantitatif, Kualitatif dan R \&. D. Bandung: Alfabeta. 2009. Metode Penelitian Kuantitatif, Kualitatif dan R\&D, Bandung: Alfabeta. 2010. Metode Penelitian Pendidikan Pendekatan Kuantitatif, kualitatif, dan R\&D. Bandung: Alfabeta. 2013. Metode Penelitian Kuantitatif Kualitatif dan R\&D. Bandung: Alfabeta. 2015. Metode Penelitian Pendidikan (Pendekatan Kuantitatif, Kualitatif dan R\&D). Penerbit CV. Bandung: Alfabeta.

Sukmadinata, 2006. Metode Penelitian Tindakan. Bandung : Remaja Rodsakarya.

Sriwahyuni, Indah dan Trestiono, Mahendro. 2017. Wawancara Profesionalisme, Gresik.

Wibowo. 2012. Manajemen Kinerja. Jakarta: Rajawali Pers. 